\title{
Työelämän asiantuntijuus ja korkeakoulupedagogiikka
}

PÄIVITYNJÄLÄ

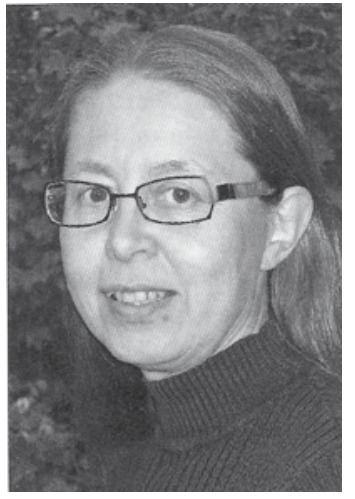

\begin{abstract}
"Korkeakouluopetuksen yksi ydinkysymys on se, millaista on asiantuntijuus, jota korkeasti koulutetuilta yhteiskunnan jäseniltä odotetaan. Tämän päivän asiantuntijatyölle on ominaista, että siinä yhdistyvät perinteiset akateemiset hyveet, kuten tieteellinen ajattelu, ja nykypäivän yhteiskunnan toiminnassa keskeisiksi nousevat verkostoitumis- ja sosiaaliset taidot. Keskeinen kysymys korkeakouluopetuksen kehittämisessä onkin se, miten voimme kehittää sellaista pedagogiikkaa, joka samanaikaisesti edesauttaa tieteellistä ajattelua ja yleisiä työelämän taitoja", kirjoittaa professori Päivi Tynjälä.
\end{abstract}

Korkeakoulupedagogiikan tutkimuspohjainen kehittäminen on voimakkaasti laajentunut kansainvälisesti, mikä on seurausta yhteiskunnan ja korkeakoulutuksen muutoksista. Työelämän nopeat muutokset, teknologian kehitys sekä tiedon tuotannon kasvu ja laajeneminen myös yliopistojen ulkopuolelle ovat johtaneet korkeasti koulutetun työvoiman tarpeen lisääntymiseen. Tästä on ollut seurauksena korkeakoulutuksen massoittuminen ja erilaistuminen. Perinteiset koulutuskäytännöt eivät välttämättä ole optimaalisia tämän päivän työelämäkompetenssien kehittämisen kannalta (ks. esim. Kauppi, 2004; Stenström, Laine \& Valkonen, 2004; Tynjälä ym. 2006), minkä vuoksi pedagogiikan uudistaminen on tärkeää. Oppimisen tutkimus on tuottanut uutta ja monipuolista tietoa oppimisen ilmiöstä, minkä seurauksena tieteelliset käsitykset oppimisesta ovat muuttuneet. On tärkeää että opetustyö pohjautuu tieteelliseen tietoon, samoin kuin vaikkapa lääkärin tai insinöörin työ.

Korkeakouluopetusta voidaan tutkimuksellisesti tarkastella monista eri näkökulmista, mutta yksi keskeisimmistä on asiantuntijuuden näkökulma eli sen tutkiminen, millaista on se asiantuntijuus, jota korkeasti koulutetuilta yhteiskunnan jäseniltä odotetaan. Kalifornian yliopiston professori Robert Reich (1995), joka toimi Clintonin hallituksessa työministerinä, on esittänyt, että valtaosa tämän päivän ja tulevaisuuden työtehtävistä voidaan sijoittaa kolmeen kategoriaan: Rutiinituotantopal- veluja on erityisesti perinteisessä teollisuudessa, ja työtehtävät ovat niissä hyvin toistuvaluonteisia. Liukuhihnatyö on tyypillinen esimerkki tästä. Toinen ryhmä on henkilöpalvelut, joissa tuotetaan palveluja ihmiseltä toiselle. Näitä ovat perinteiset palveluammatit. Kolmatta ryhmää Reich ja toinen tunnettu tietoyhteiskuntateoreetikko Manuel Castells (2000) kutsuvat symbolianalyyttisiksi tehtäviksi. Niissä ei suoraan valmisteta tuotteita tai anneta palveluja vaan tunnistetaan ja ratkaistaan ongelmia käsittelemällä symbolista informaatiota. Tällaisia tehtäviä tekevät eri aloilla esim. suunnittelijat, konsultit, projektipäälliköt, insinöörit, tutkijat, toimittajat, mainonta- ja markkinointi-ihmiset jne. Korkeakoulutuksen tehtävä on tuottaa osaajia nimenomaan näihin symbolianalyyttisiin tehtäviin, joissain määrin myös henkilöpalveluihin ja sellaisiin tehtäviin, joissa yhdistyvät henkilöpalvelut ja symbolianalyysi.

Korkeakouluopetuksen kehittämisen kannalta yksi tärkeä kysymys onkin, minkälaista osaamista symbolianalyyttisessä työssä tarvitaan. Robert Reichin mukaan oman alan substanssiosaamisen lisäksi tiedon käsittelyn taidot ovat ensiarvoisia. On osattava löytää oikeata tietoa, tarkastella kriittisesti valtavaa informaation tulvaa, analysoida tietoa ja tehdä siitä synteesejä. On pystyttävä myös näkemään mihin laajempiin kokonaisuuksiin asiat liittyvät, eli tarvitaan abstraktia ajattelua ja kokonaisvaltaista järjestelmäajattelua. Jotta pys- 
tytään tuottamaan uusia ideoita, tarvitaan myös uskallusta, innovatiivisuutta, kokeilunhalua ja visiointikykyä, ehkä jossain määrin myös riskinottokykyä. Symbolianalyyttisessä työssä on yksilöllisen työn vaiheita, mutta tyypillistä sille on erilaisissa verkostoissa, tiimeissä ja yhteistyöryhmissä toimiminen. Työ sisältää paljon kokouksia, neuvotteluja, esitelmiä, raportointia, muistioiden tekemistä jne. Tällaiset tehtävät edellyttävät vahvoja sosiaalisia taitoja ja viestintätaitoja. On tärkeää että asiantuntija osaa viestittää asiansa paitsi oman alan asiantuntijoille, myös eri alojen edustajille ja maallikoille.

Kaiken kaikkiaan tämän päivän asiantuntijatyölle on ominaista, että siinä yhdistyvät perinteiset akateemiset hyveet, kuten tieteellinen ajattelu, ja nykypäivän yhteiskunnan toiminnassa keskeisiksi nousevat verkostoitumis- ja sosiaaliset taidot. Keskeinen kysymys korkeakouluopetuksen kehittämisessä onkin, miten voimme kehittää sellaista pedagogiikkaa, joka samanaikaisesti kehittää tieteellistä ajattelua ja yleisiä työelämän taitoja.

\section{Asiantuntemus kehittyy työssä}

Koulutuksen tutkimuslaitoksessa on tehty useita tutkimuksia siitä, miten yliopistoista ja ammattikorkeakouluista valmistuneet ovat sijoittuneet työelämään, minkälaisia taitoja he työssään tarvitsevat ja minkälaisia valmiuksia koulutus on työhön antanut (esim. Stenström 2006; Tynjälä ym., 2006; Vuorinen \& Valkonen 2007). Yksi näistä tutkimusta koski sellaisia Jyväskylän, Helsingin ja Turun yliopistosta valmistuneita, joilla oli kahdesta kymmeneen vuoteen työkokemusta (Tynjälä ym. 2006). Mukana oli neljä alaa: opettajankoulutus, kasvatustiede, tietotekniikka ja tietojärjestelmätiede sekä farmasian ala. Kun valmistuneilta kysyttiin, mitä taitoja he tarvitsevat eniten, kaikilla aloilla sosiaaliset taidot nousivat kärkeen. Tutkimus osoittaa, että tietoyhteiskuntateoreetikoiden näkemyksillä on myös selvää empiiristä pohjaa.

Kun samoilta tutkittavilta kysyttiin, missä tärkeimmät työssä tarvittavat taidot oli opittu, noin 64 prosenttia vastasi, että ne on opittu työssä, ja vain 14 prosenttia koki, että ne on opittu yliopistossa. 10 prosenttia vastasi, että ne on opittu sekä yliopistossa että työssä. Kun tulosta tarkastellaan, on muistettava, että osa yliopistokoulutuksen tuottamasta osaamisesta voi olla vaikeasti tunnistettavaa ja toisaalta mitä pitempään koulutuksesta on kulunut, sen vaikeampaa on hahmottaa se hyöty mikä koulutuksesta on ollut. Toisaalta tulos kertoo siitä, että työpaikat ovat akateemisille työntekijöille tärkeitä oppimisympäristöjä. Tämän vuoksi onkin syytä pohtia, olisiko korkeakoulutuksen lisättävä yhteistyötä työelämän kanssa ja olisiko kehitettävä sellaista pedagogiikkaa, jossa opiskelijat pääsevät ratkaisemaan aitoja työelämän ongelmia jo opiskelun aikana.

Tällaisen pedagogiikan kehittämiseen tarvitaan näkemystä siitä, mistä elementeistä korkeatasoinen asiantuntijuus koostuu ja miten asiantuntijuuden kehittymistä voidaan edistää. Asiantuntijuustutkimuksessa on esitetty erilaisia luokitteluja asiantuntijuuden komponenteista ja taulukossa 1 on rinnakkain kaksi luokitusta, vasemmalla yksityiskohtaisempi ja oikealla hieman yleisempi (ks myös Bereiter 2002; Eraut, 2004; Le Maistre \& Paré, Tynjälä 2008). Ensinnäkin kaikilla aloilla on olemassa tiettyä perustietoa, josta tieteentekijöiden piirissä ollaan yksimielisiä - eli kyse on yleisesti hyväksytystä, vakiintuneesta faktuaalisesta tiedosta. Tämä on tyypillistä peruskursseilla opetettavaa tietoa. Sitä abstraktimmalla tasolla on käsitteellinen tieto, eli erilaiset teoreettiset mallit ja käsitejärjestelmät, joilla todellisuutta kuvataan teoreettisemmalla tasolla. Näitä kahta tiedon lajia voi yhteisellä nimellä kutsua formaaliseksi eli muodolliseksi tiedoksi tai teoreettiseksi tiedoksi. Tämä tie-

Taulukko 1: Asiantuntijuuden elementit
1. Faktuaalinen tieto
2. Käsitteellinen tieto
3. Proseduraallinen tieto/ taidot (know how)
4. Äänetön tieto, intuitio
5. Metakognitio, reflektiivinen tieto

1. Formaalinen/ teoreettinen tieto

2. Käytännöllinen/ kokemuksellinen tieto

3. Itsesäätelytieto

Korkeatasoisessa asiantuntijuudessa elementit ovat integroituneet tiiviisti; perinteisessä koulutuksessa ne ovat erillisiä.

(Bereiter \& Scardamalia 1993; Bereiter 2002; Eraut 2004; La Maistre \& Pare 2006; Tynjälä 2008) 
to on luonteeltaan eksplisiittistä eli ilmaistavissa olevaa tietoa eli sitä voidaan helposti kuvata esimerkiksi luennoilla tai oppikirjoissa. Tärkeä osa asiantuntijuudessa on myös tiedolla, jota tutkijat kutsuvat proseduraaliseksi tiedoksi. Se on tietoa siitä, miten jotkut proseduurit ja toimenpiteet suoritetaan - tiedetään kuinka jokin asia tehdään. Tästä tulee englanninkielessä paljon käytetty termi "know how”. Suomeksi voidaan yksinkertaisesti puhua taidoista tai käytännöllisestä tiedosta. Tällainen tieto syntyy nimenomaan käytännön kokemuksen kautta ja siitä käytetään myös nimitystä kokemuksellinen tieto.

Korkeatasoisessa osaamisessa ja asiantuntijuudessa on tyypillistä myös hiljainen tieto tai äänetön tieto, tacit knowledge. Tämä on intuition kaltaista tietämystä, jota on vaikea ilmaista ja pukea sanoiksi. Sitä ei pystytä helposti ilmaisemaan sen takia, että sitä ei opita kirjoista, vaan se syntyy nimenomaan kokemuksen kautta.

Lisäksi asiantuntijuustutkimuksessa on todettu, että asiantuntijoilla on hyvät metakognitiiviset ja reflektiiviset taidot, joita voi yhteisellä nimellä kutsua itsesäätelytaidoiksi. Niillä tarkoitetaan omaan toimintaan, oppimiseen, tietämiseen ja osaamiseen kohdistuvia tietoja ja taitoja. Esimerkiksi omien vahvuuksien ja heikkouksien tuntemus on osa itsesäätelytietoa. Siihen liittyy myös oman toiminnan kriittinen tarkastelu ja ohjaus.

Korkeakoulupedagogiikan kannalta kiinnostavaa on se, että korkeatasoisessa asiantuntemuksessa nämä eri elementit eivät ole erillisiä toisistaan vaan ne ovat tiiviisti toisiinsa integroituneet. Asiantuntijan ei tarvitse erikseen miettiä, mihinkä teoriaan hän pohjaisi jonkun päätöksensä, vaan hänen tietonsa ja taitonsa ja oman toiminnan ohjaus toimivat joustavasti toisiinsa sulautuneena. Mitä korkeammantasoisesta asiantuntijuudesta on kyse, sen tiiviimmin asiantuntijuuden eri elementit ovat integroituneet toisiinsa (Bereiter 2002). Korkeakouluopetuksen kannalta tästä seuraa, että asiantuntijuutta voidaan parhaiten kehittää integroimalla asiantuntijuuden komponentteja toisiinsa. Perinteisissä koulutusmalleissa ne ovat kuitenkin olleet erillisiä. Ensimmäisinä opiskeluvuosina on opiskeltu teoreettista tietoa ja opintojen loppuvaiheessa on ollut harjoittelujakso, jossa on saatu käytännön kokemusta ja kokemuksellista tietoa. Perinteisissä malleissa harjoittelua ei ole yleensä mitenkään ole kytketty teoreettisiin opintoihin. Itsesäätelytieto on perinteisessä koulutusmallissa usein kokonaan jätetty huomiotta tai sitä edustaa opintojen alkuvaiheessa opiskelutaitojen kurssi - joilla tutkimusten mukaan muusta opetuksesta erikseen järjestettynä ei ole paljon hyötyä.

\section{Kohti interagratiivista pedagogiikkaa}

Olen kutsunut integratiiviseksi pedagogiikaksi sellaista koulutusmallia, jossa oppikurssit ja opintojaksot järjestetään niin, että kaikki asiantuntijuuden elementit ovat mukana ja niitä kytketään toisiinsa samalla opintojaksolla (ks. Tynjälä 2008). Teoreettista tietoa muunnetaan sellaiseen muotoon, että sitä voidaan hyödyntää käytännön tilanteissa ja vastaavasti käytännön harjoitteluissa, simulaatioissa, projektitöissä tai eksperimenteissä syntyvää kokemuksellista tietoa käsitteellistetään (ks Leinhardt ym. 1995). Teoriaa käsitellään siis kokemuksen valossa ja käytännön kokemuksia teorian valossa. Samalla teoriaa, käytäntöä ja niiden yhteyttä reflektoidaan omassa toiminnassa, mitä kautta itsesäätelytieto kehittyy. Tähän tarvitaan erilaisia välineitä, joita voivat olla esimerkiksi kirjoitustehtävät, joiden kautta pohdiskellaan teorian ilmenemistä käytännössä tai analysoidaan käytännön tilanteita teorian valossa. Esimerkiksi oppimispäiväkirjaa voi soveltaa tällä tavoin. Yksi tapa on hyödyntää kollaboratiivista oppimista, keskusteluja ja kokemusten jakamista muiden kanssa. Tutorointia, mentorointia ja valmennusta voidaan myös toteuttaa tämän periaatteen mukaisesti eli tutori ohjaa teorian ja käytännön toisiinsa kytkemiseen ja tukee reflektointia.

Käytännössä integratiivista pedagogiikkaa voi toteuttaa monella eri tavalla. Opinnoissa voi olla esimerkiksi työelämäprojekteja, joissa opiskelijaryhmät tekevät oikeille yrityksille tai muille työelämän organisaatioille projektitöitä. Prosessissa yhdistetään teoriaa ja käytäntöä ja reflektoidaan oman työn kriittisiä vaiheita ja osaamisen kehittymistä. Myös työharjoittelu on erinomainen mahdollisuus integratiivisen pedagogiikan toteuttamiseen, mutta se edellyttää sitä, että harjoitteluun liittyy teoriaa ja käytäntöä kytkeviä oppimistehtäviä, ryhmäkeskusteluja, oppimispäiväkirjan kirjoittamista jne. Harjoittelu on siis toteutettava ohjatusti niin, että sillä on yhteys teoreettisiin opintoihin ja sen tulee sisältää käytännön kokemuksen reflektointia.

Usein opiskelijat ovat oman alansa töissä myös opiskeluaikana ja varsinkin aikuisopiskelijoilla se on tavallista. Silloin voidaan hyödyntää tätä työkokemusta siten, että järjestetään sellaisia opiske- 
lumuotoja, joissa työtä tarkastellaan teoreettisen tiedon valossa esim. esseissä, oppimispäiväkirjassa, portfoliossa tai ryhmäkeskusteluissa. Työkokemuksen ja arkioppimisen hyödyntäminen osana muodollista koulutusta on maailmalla nousussa, ja esimerkiksi eräässä EUn rahoittamassa projektissa tällaista pedagogiikkaa kehitetään yliopistokoulutukseen (http://www.icll.gcal.ac.uk/lifelearn/index.html). Edellä mainitut integratiivisen pedagogiikan toteuttamistavat liittyvät vahvasti aitoihin työympäristöihin. Kaikilla opintojaksoilla ei kuitenkaan ole mahdollista eikä tarpeenkaan lähteä oikeaan työelämään. Silloin voidaan kuitenkin tehdä eräänlaista kuivaharjoittelua tai mielikuvaharjoittelua niin kuin urheilijat tekevät. Voidaan toteuttaa esimerkiksi simulaatioita joissa harjoitellaan työelämän tilanteita, tai voidaan käyttää ongelmalähtöistä oppimista, joissa opiskelun lähtökohtana ovat aidot työelämän ongelmat. On myös mahdollista liittää perinteisiin teoriakursseihin, luentoihin ja kirjojen opiskeluun erilaisia sovellustehtäviä, joita käsitellään sekä kirjallisesti että suullisesti.

Kaikille näillä pedagogisille ratkaisuille on yhteistä, että samalla kun niissä opiskellaan substanssitietoa teoriaa ja käytäntöä kytkien, opitaan myös tärkeitä työelämätaitoja, kuten sosiaalisia taitoja ja viestintätaitoja. Integratiivinen pedagogiikka onkin tulevina vuosina yksi tärkeitä korkeakoulupedagogisen tutkimuksen teemoja.

\section{Lähteet}

Bereiter, C. (2004). Education and mind in the knowledge age. Mahwah, NJ: Erlbaum.

Castells, M. (2000). The rise of the network society. Second edition. Oxford: Blackwell.

Eraut, M. (2004). Transfer of knowledge between education and workplace settings. Teoksessa H. Rainbird, A. Fuller \& A. Munro (toim) Workplace Learning in Context, London: Routledge, 201-221.

Kauppi, A. (2004). Työ muuttuu - muuttuuko oppiminen? Teoksessa P. Tynjälä, J. Välimaa \& M. Murtonen (toim.). Korkeakoulutus, oppiminen ja työelämä. Pedagogisia ja yhteiskuntatieteellisiä näkökulmia, 187-212.

Leinhardt, G., McCarthy Young, K. \& Merriman, J. (1995). Integrating professional knowledge: The theory of practice and the practice of theory. Learning and Instruction 5, 401-408.
Le Maistre, C \& Paré, A. (2006). A typology of the knowledge demonstrated by beginning professionals. Teoksessa P. Tynjälä, J. Välimaa \& G. Boulton-Lewis (toim.) Higher education and working Life. Collaborations, confrontations and challenges. Amsterdam: Elsevier, 103-113.

Markovitsch, J. \& Messerer, K. (2006). Practiceoriented methods in teaching and learning in higher education: theory and empirical evidence. Teoksessa P. Tynjälä, J. Välimaa \& G. Boulton-Lewis (toim.) Higher education and working life. Collaborations, confrontations and challenges. Amsterdam: Elsevier, 177-194.

Reich, R. (1995). Rajaton maailma. Yritysten ja kansallisvaltioiden uudet pelisäännöt. Suom. Sami Kangasharju. Helsinki: SITRA.

Stenström, M-L. (2006). Polytechnic graduates' working-life skills and expertise. Teoksessa. P. Tynjälä, J. Välimaa \& G. Boulton-Lewis (eds.) Higher education and working life. Collaborations, confrontations and challenges. Amsterdam: Elsevier, 89-102.

Stenström, M-L, Laine, K. \& Valkonen, S. (2004). Ammattikorkeakoulusta valmistuneiden sijoittuminen työelämään. Teoksessa P. Tynjälä, J. Välimaa \& M. Murtonen (toim.) Korkeakoulutus, oppiminen ja työelämä. Pedagogisia ja yhteiskuntatieteellisiä näkökulmia, 109-125.

Tynjälä, P. (2008). Integratiivinen pedagogiikka osaamisen kehittämisessä. Teoksessa H. Kotila, A. Mutanen \& M V Volanen (toim.) Taidon tieto. Helsinki: Edita, 11-36.

Tynjälä, P., Slotte, V., Nieminen, J. Lonka, K. \& Olkinuora, E. (2006). From university to working life: Graduates’ workplace skills in practice. Teoksessa P. Tynjälä, J. Välimaa \& G. BoultonLewis (toim.) Higher education and working life. Collaborations, confrontations and challenges. Amsterdam: Elsevier, 73-88.

Vuorinen, P. \& Valkonen, S. (2007).Korkeakoulutuksesta työelämään. Työhön sijoittuminen ja työelämävalmiudet kaupan ja tekniikan alalla. Jyväskylän yliopisto. Koulutuksen

Päivi Tyimualanlaitos. virkananastujaispuhe Jyväskylän yliopistossa 7.5.2008. Professuuri sijoittuu koulutuksen tutkimuslaitokseen KTL:ään. Päivi Tynjälä on toiminut tutkimusprofessorina ja määräaikaisena professorina vuodesta 2002 lähtien. 